\title{
Mini review on phenol biodegradation in Antarctica using native microorganisms
}

\author{
Kavilasni Subramaniam, Siti Aqlima Ahmad ${ }^{\mathrm{a}, \mathrm{b}^{*}}$, Noor Azmi Shaharuddin ${ }^{\mathrm{a}}$ \\ ${ }^{a}$ Department of Biochemistry, Faculty of Biotechnology and Biomolecular Sciences, Universiti Putra Malaysia, 43400 UPM, Serdang, Selangor, \\ Malaysia \\ ${ }^{b}$ National Antarctic Research Centre, B303 Level 3, Block B, IPS Building, Universiti Malaya, 50603 Kuala Lumpur, Malaysia
}

Received 6th February 2019 / Accepted 12th February 2020

\begin{abstract}
Though Antarctica has once been considered as the most pristine land on earth, however, recently many literatures concluded that it is not a zone free from anthropogenic pollutants, which have been mostly associated with long-range atmospheric transport and deposition in the area. Numerous organic pollutants including phenol have been classified as the priority pollutants by the United States Environmental Protection Agency (US EPA) due to their high toxicity. The increased level of phenol concentration in the Antarctic environment poses a significant risk to the aquatic as well as terrestrial lives and public health due to its persistence, biomagnification and accumulation in the food chain. Therefore, bioremediation actions are significant to overcome this problem. Phenol degradation at cold climate needs the use of microorganisms that has the ability to thrive and function at low temperatures as well as withstand the toxicity of phenol. The utilisation of native microbes as phenol-degraders has proven the effectiveness of bioremediation even though phenol has anti-microbial properties. This paper discusses the sources and toxicity of phenol, existence and effect of phenol on the Antarctic environment, the potential method for eliminating phenol from the environment and suggestion for future prospect.
\end{abstract}

Keywords: Antarctica, bioremediation, cold-adapted microorganism, mixed culture, phenol

\section{INTRODUCTION}

Located in the southernmost continent and overlying the South Pole, Antarctica is known to be world's fifth largest continent with an area of roughly 13.8 million $\mathrm{km}^{2}$, which is 58 times the area of United Kingdom (Royal Geographical Society, 2018). This highly elevated land of Antarctica is identified as virtually uninhabited as well as ice-covered landmass. Known as the driest and windiest place in the world, this continent is challenged with extreme temperature as well as seasonal fluctuation in water availability. This harsh environment together with exposure of solar radiation made life in this icy desert to be extremely difficult (Bramley-Alves et al., 2014). Despite this, there are some exemptions for extremophiles that can acclimatise to the low temperatures, aridness, and high exposure that are common in Antarctica.

This pristine continent plays a significant part in the global climate dynamics and comprised the largest reservoir with $90 \%$ of the earth's obtainable freshwater (Neto et al., 2017). In line with its simple ecosystem, Antarctica is very vulnerable to man-made changes especially pollution that can result in larger adverse effects. Despite the strict rules provided in the Protocol

*Author for correspondence: Siti Aqlima Ahmad, Department of Biochemistry, Faculty of Biotechnology and Biomolecular Sciences, Universiti Putra Malaysia, 43400 UPM Serdang, Selangor, Malaysia. Email aqlima@upm.edu.my 
of Environmental Protection to the Antarctic Treaty for protection of the Antarctic environment, the menace of pollution from daily waste discharge and accidental oil spills still occur as a result of increasing activities in the continent including those related to the study and supply of research stations, tourism, fishing, as well as marine transportations (Brown et al., 2017). Previous and present improper waste managing practices caused the release of contaminants especially hydrocarbon pollutants from terrestrial activities into the near-shore aquatic environment. The terrestrial activities here are mainly referred to the occurrence of oil spill due to the transport of fuel to powerhouses as well as fuel spill while refilling fuel tanks and vehicles. The fuels usually used in Antarctica are gasoline, lubricant oil as well as diesel, which comprised high content of phenolic compounds (Roslee et al., 2019; Vázquez et al., 2017).

Phenol, as a persistent organic pollutant (POP), becomes a topic of special attention since cold temperature has a significant effect on the biodegradation rate of the pollutant by altering its physical nature like increasing viscosity, decreasing volatilisation and reducing its bioavailability (Bajaj \& Singh, 2015). Natural degradation in low temperature is far slower compared to other parts of world, making it possible for the pollutant to accumulate and bioaccumulate in the environment (Zakaria et al., 2019). For instance, phenol and its derivatives require decades to be completely degraded in cold region, whereas only months are needed for the pollutants to be fully removed in temperate region. Phenol and its derivatives have been categorised as among the 65 priority pollutants by US EPA since they are highly toxic, corrosive, poorly biodegrade and can bioaccumulate in living organisms. Besides, they are known to cause harm to the environment, aquatic as well as terrestrial lives including human. Therefore, it is crucial to have possible eco-friendly and cost-effective approach to overcome this pollution without resulting in secondary pollution. This has led to the development of a new green technology in bioremediation inclusive of biodegradation, which was to remediate this pollution using microorganisms.

The basis of biodegradation technique is the natural capability of microbial species to degrade organic compounds. This technology is responsible for the completely mineralising complex substances into simpler ones such as carbon dioxide, water, nitrate and other inorganic compounds (Nair et al., 2008). Basically, microbial species find their food in the environment they live in like soil and water; thus, if a pollutant is present in their environment, it can become an additional food source for them. These microbial species acquire their source of carbon essential for their growth from this pollutant. Moreover, these microorganisms use the pollutant for their energy source by breaking the chemical bonds and transferring the electrons away from the pollutant. The microorganisms use the energy produced as a result of electron transfer along with the carbon source for the multiplication of more cells (Kulshreshtha et al., 2014).

In this case, phenol and its derivatives are not easily biodegradable and can inhibit the distinctive action of most types of microbial species, either at higher or lower concentrations due to the inhibition of substrates produced in high concentration, hindering the microbial growth and associated biodegradation of phenol (Senthilvelan et al., 2014). In addition, the harsh environment of Antarctic continent is a great challenge for the microbes to naturally degrade the pollutants. Hence, it has become the major topic in environmental studies together with the study of the main mechanism of bio-removal of this phenol from contaminated sites. Endeavours to remediate contaminated sites in Antarctica have been done by utilising physical and chemical strategies. Nevertheless, the estimated budget for the transportation and usage of physical machinery was high due to the remote and extreme condition of the continent. Besides, chemical method may introduce some toxic compounds to the environment, which may lead to secondary pollution (Habib et al., 2018).

In recent years, naturally occurring defined microorganisms with the ability to tolerate phenol have been widely used as a new tool in biodegradation to degrade highly toxic phenol and its derivatives into less toxic or innocuous compounds with cost effective, simple yet publicly accepted technology that can often be carried out (Al_Defiery \& Reddy, 2014). In accordance with that, this mini review was written with the intention to provide fundamental 
knowledge on biodegradation of phenol in Antarctica with specific examples of recent observations in the context of application.

\section{Phenol and its toxicity}

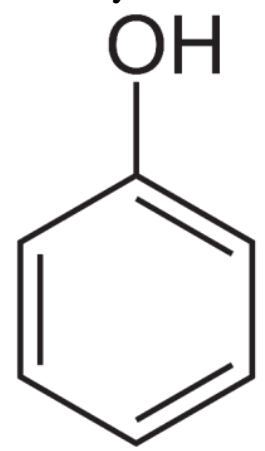

Figure 1. Chemical structure of phenol (Basha et al., 2010).

Phenol, a chemical compound included in the aromatic hydrocarbon group, is also known by many names such as hydroxybenzene, phenic acid, phenelic acid, carbolic acid or phenol alcohol. Generally, degradation and oxidation of polyaromatic organic compounds including benzene and polymers will result in the production of phenol (Naghan et al., 2015). It has the structural formula of $\mathrm{C}_{6} \mathrm{H}_{5} \mathrm{OH}$ (Figure 1) with percentage composition of $76.57 \%$ carbon, $17 \%$ oxygen and $6.43 \%$ hydrogen and molecular weight of $94.11 \mathrm{~g} / \mathrm{mol}$ (Babich \& Davis, 1981). This colourless, needle-like crystalline substance has a characteristic odour, corrosive nature and considerably soluble in water as well as organic solvents including petroleum, alcohol, chloroform, glycerol, and ether (Mazuki et al., 2019; Babich \& Davis, 1981).

From the positive side, phenol and its derivative play a significant role in many industries where they are used as essential raw material in many manufacturing and processing industries such as oil refining, pharmaceutical, cosmetics, pesticides, resin products and coking plants (Senthilvelan et al., 2014). For instance, phenol plays key role in the plastic manufacturing including polycarbonates, bisphenol- $A$, and phenolic resins. Phenol also becomes the main constituent in cosmetic products like hair dyes, lipsticks, sunscreens and skin lightening agents (Ni et al., 2011). Furthermore, phenol is used as a significant raw material in leather industry for synthetic tanning material production (Senthilvelan et al., 2014).
Despite of the numerous beneficial properties, phenol has been inscribed in the list of top 65 priority pollutants by the US EPA due to its highly toxic, mutagenic as well as carcinogenic properties (Ahmad et al., 2012). Its resistance to degradation and being persistent in the environment result in a long-range transportation and bioaccumulation in living organisms, which then lead to biomagnification in the food chain. Concerning this issue, the international act as well as several profit and non-profit agencies of each nation such as EPA, and WHO have set certain limit for the level of phenol content in drinking water and effluent (Mazuki et al., 2019). For instance, the EPA has proposed a limit of 0.001 $\mathrm{mg} / \mathrm{L}$ for phenol in surface water as the noxiousness levels generally are in the range of 9$25 \mathrm{mg} / \mathrm{L}$ for both human and aquatic life (Villegas et al., 2016).

Acute or chronic exposure of phenol can result in harmful effect in human. Acute exposure to phenol can result in skin irritation, gastrointestinal discomfort as well as headache. The corrosive nature of phenol can cause chemical burns at the contact site (Basha et al., 2010). Not only that, phenol can be highly dangerous when it comes into contact with eyes as it can cause impaired vision (Abussaud et al., 2016). Since phenol has a local anaesthetic effect, minute or no pain may be felt on initial contact. The skin damage caused by phenol is resulted from coagulation related to reaction to phenol with amino acids contained in keratin of epidermis and collagen in inner skin. Repeated or prolonged exposure to phenol or its vapour can be toxic to the nervous system, heart, kidneys, and the liver since it is readily absorbed through skin and mucosa (Pradeep et al., 2015). A study has been carried out using ground water that has been contaminated with phenol, which was used for drinking purpose. It was evaluated that the daily exposure to the phenol was ranged between 10$240 \mathrm{mg}$ per person and the result demonstrated a significant increase in the cases of diarrhoea, mouth sores and excretion of dark urine (Michalowicz \& Duda, 2007). Additionally, the toxic effects of phenol include permeabilisation of cellular membranes as well as cytoplasmic coagulation (Vasudevan, 2014). Phenol inhibits the synthesis and replication of DNA in cells and has the ability to stop DNA preparation in diploid 
human fibroblasts (Pradeep et al., 2015). Some studies discussed that phenolic compounds may pose possible risks on human health including cancer, cardiovascular disease, diabetes, decreased immunisation and endocrine (An et al., 2014; Barrett, 2010; Henry \& Fair, 2013; Krause et al., 2012). Also, in some experimental studies, it has been reported that the consumption of phenol can lead to abortion and increased arrest of early embryonic development (de Renzy-Martin et al., 2014).

Besides, phenol also pose toxic effects on terrestrial as well as aquatic animals. Duan et al. (2018) reported that phenol concentration more than $9 \mathrm{mg} / \mathrm{L}$ had caused mortality in fish and crustaceans and when the concentration exceeded $100 \mathrm{mg} / \mathrm{L}$, it caused mortality in molluscs and rotifer. Studies also reported that once phenol entered into the system of fish, it can adversely affect the reproduction potential, survival and growth as well as its metabolism (Mukherjee et al., 1991; Saha et al., 1999). In addition, phenol pollution also resulted in the decrease of algal growth and population. On the other hand, phenolic derivatives exhibit toxic effects in domestic animals by malfunctioning their biochemical system and causing reproductive impairment (Yahaya et al., 2019). Phenol and its substituted phenolic compounds have been known to cause much negative impacts to the environment and result in the deterioration of the water environment.

\section{Phenol existence in the Antarctic environment}

There have been several major events reported in association with the oil spill, which led to phenol pollution in Antarctica. For instance, a major fuel spill has occurred in 1989 when the Argentine Polar Transporter, Bahia Paraiso that was en route to resupply Argentine research station ran aground and sank near Palmer Station, Antarctica releasing over 150000 gallons of diesel (Brown et al., 2017). Besides, a Chilean ship, known as the Patriarche, undergone shipwreck and spilled 1500 $\mathrm{L}$ of diesel off the north-west Antarctic coast in the year 2001 (CEP-IV-IP62, 2001). In addition, there are reports stating that areas neighbouring Old and New Casey stations in Antarctica have been contaminated by major spills of petroleum substances along with many minor spills due to daily operations (Powell et al., 2003). Phenol contamination still occurs to date mainly due to oil spillage. The most recent major oil spill was occurred in November 2007 when an adventure travel ship named MS Explorer carrying $1200 \mathrm{~L}$ of petrol, $24000 \mathrm{~L}$ of lubricant oil and $190000 \mathrm{~L}$ of marine gas oil hit an iceberg and sank near the Antarctic water (Stark et al., 2017) followed by the occurrence of diesel spill at Carlini Station, King George Island in 2009 (Vázquez et al., 2017). These marine accidents then created a passage for the POPs like phenol to travel to other parts via physical and chemical processes; for instance, the addition of dispersants, shoreline erosion, water washing, or volatilisation, Yet, the toxicity of these compounds remains intact throughout the transportation (Pi et al., 2016). Besides, increasing number of research stations become the main reason for the majority of terrestrial fuel spills on the ice-free lands that make up about $0.3 \%$ of the Antarctic continent (McWatters et al., 2016). Moreover, daily waste discharged from coastal research stations were also dumped in the soil and water bodies of Antarctica, which then resulted in increased level of phenol pollution. On the other hand, natural processes like the formation of phenol and p-cresol during organic matter decomposition or synthesis of chlorinated phenols by fungi and plants can also cause phenol occurrence in this Antarctic environment (Roy et al., 2015). Phenol is also formed in the form of hydroxybenzene as a side product of chemical reactions occurred in the atmosphere in condensed water vapour during the formation of clouds (Zaki et al., 2015).

The phenol-derived pollutants in Antarctica tend to be persistent in the environment as a result of the continent's harsh environment. For instance, extremely low temperature and dry condition, sea ice, as well as the continent's remoteness become the greatest challenge as they limit the rate of bioprocesses as well as abiotic degradation. According to Stark et al. (2017), the hydrocarbon pollutants including phenol and its derivatives in Antarctic environment can be seen for more than five years of post-event and had a significant and long-term impact on the structure and diversity of sea floor invertebrates like roundworms and small crustaceans like nematodes and copepods, respectively. As a matter of fact, these sediment-dwelling creatures 
exhibit a vital role in recycling organic compounds and nutrients in sea bed communities as well as provide food for larger organisms.

Since phenol contaminants are exposed to Antarctic environment majorly due to oil spill, they exhibit negative effect on both Antarctic terrestrial as well as aquatic animals. For instance, oil spill occurrences have large adverse effects especially on penguins that regularly dive through dense diesel plume in terms of physiological immunosuppressive mechanisms as well as energy metabolism (Braun et al., 2014). Besides, the Antarctic seabirds are largely seemed to be smothered with crude oil, which can result in instant death due to suffocation. Crude oil with high phenol content can disrupt their feather integrity by insulating the air between feathers, which cost the buoyancy, thermal insulation and water-proofing ability, hence making them incapable of diving or flying. In addition, these contaminated seabirds encounter a relatively rapid depletion of fat reservoir, making them extremely emaciated and hypothermic, thus resulting in mortality (Troisi et al., 2016).

In Antarctica, photosynthetic efficiency of mosses like Schistidium antarctici and Ceratodon purpureus was severely inhibited due to the fuel contamination (Nydahl et al., 2015). Concurrently, reports by Cox (1996), Song \& Huang (2007), and Park et al. (2012) proved that phenol exposure on the plants resulted in the loss of chlorophyll due to the damage in chloroplasts. Generally, there are studies reporting that phenol has the tendency to cause endocrine disruption in aquatic lives and lead to depletion of aquatic ecosystem because of its perceived bioaccumulative characteristics (Millow, 2015; Plahuta et al., 2017). In concordance, Antarctic marine environment comprising variety of fauna, for instance, bald notothen fish (Pagothenia borchgrevinki) (Almroth et al., 2015), Antarctic dragonfish (Gymnodraco acuticeps) (Flynn et al., 2015), Antarctic krill (Euphausia superba) (Sontag et al., 2019), Antarctic shrimp (Chorismus antarcticus) (Toullec et al., 2017), and gastropod mollusc (Nacella polaris, Laevilitorina caliginosa) (Griffiths \& Waller, 2016) has high risk of being affected by this phenol pollution.

Soil and gravel in Antarctica are considered as valuable resources and phenol contamination mainly due to oil spills on land and improper waste disposal by research stations compromise these precious resources (McWatters et al., 2016). Also, the simple biological communities of Antarctica are very vulnerable to these kinds of pollutions and easily get affected by the toxic effects. In order to ensure a balanced ecosystem and sustainable quality of Antarctic environment, it is highly important to find a solution to overcome this extremely hazardous phenol pollution because the ecosystem recovery is suppressed by multiple factors like extreme temperatures, low nutrients content as well as low moisture content in the continent. The necessity to remediate polluted environment has led to the development of new technologies that accentuate the degradation of pollutants rather than the conventional approach of disposal.

\section{Remediation of phenol using microorganisms}

There are plenty of methods utilised by researchers to remove organic pollutants like phenol from the environment as shown in Table 1.

Considering the disadvantages of these methods, researchers widely use biological method when it comes to removing pollutants from the environment. Especially, bioremediation approach which uses microorganisms or microbial processes to degrade environmental contaminants has been gaining much recognition among the researchers. It is recognised as a technology that can convert contaminants into less harmful forms by different types of microorganisms such as bacteria, fungi, algae and their produced substances (Joutey et al., 2013; Kanematsu \& Barry, 2015). Bioremediation technologies can be widely categorised into ex situ and in situ where ex situ technologies involve physical removal of contaminated material for treatment process, whereas in situ technologies involve treating the contaminated material on site. Bioremediation technology has several benefits over conventional where it can be done on site, cost effective and cause minimal site disruption. Moreover, this technology is capable of eliminating waste permanently and long-term liability, and has better public acceptance (Sivakumar et al., 2014). 
Table 1. Methods involved in the removal of phenol from the environment.

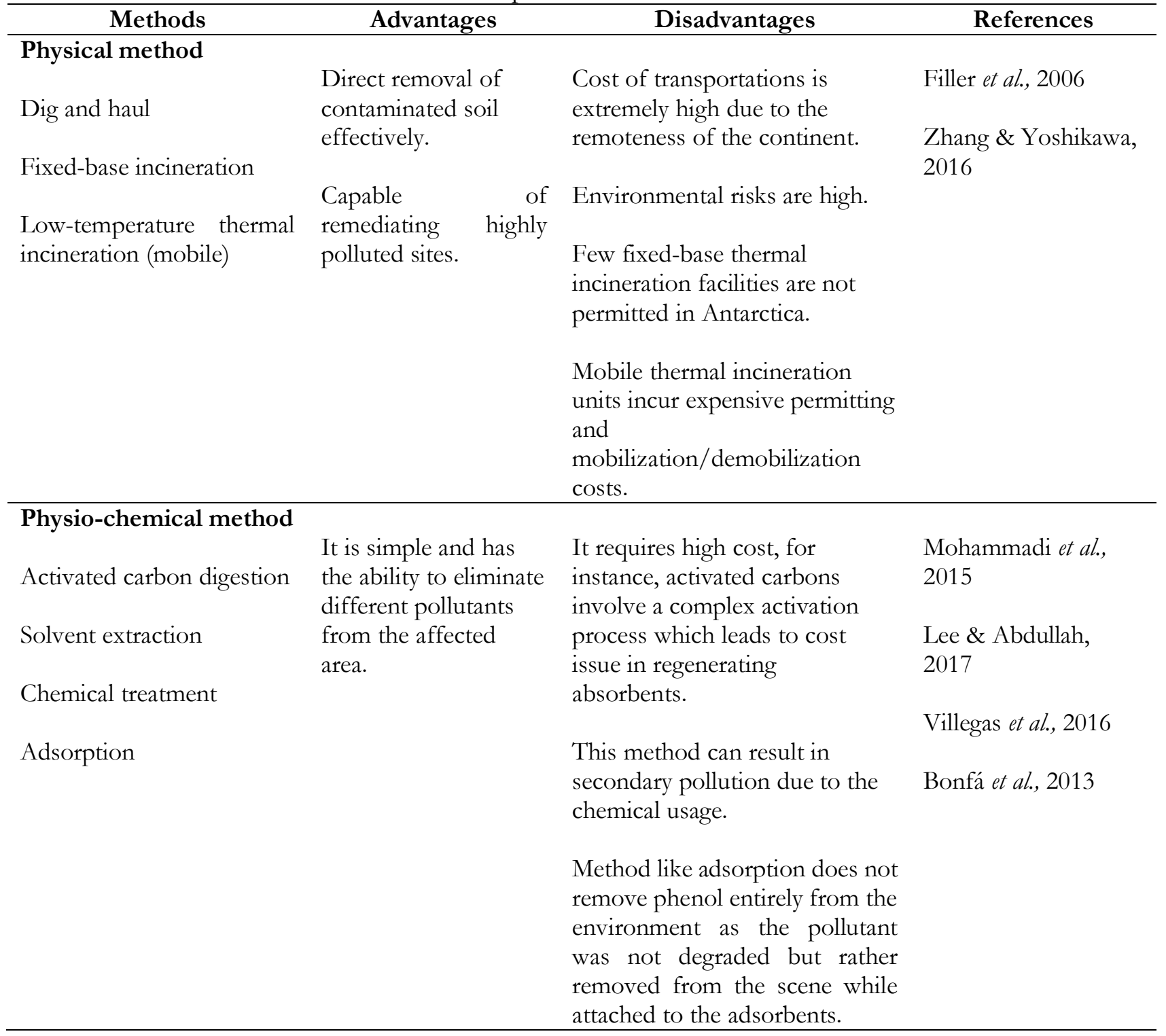

Bioremediation process comprised three phases; first, via natural attenuation involving processes like biodegradation, dispersion, sorption, volatilisation, as well as biochemical stabilisation where pollutants are reduced by native microorganisms without any human augmentation while second level involves biostimulation where nutrients and oxygen are applied to the systems to improve their effectiveness as well as to hasten the biodegradation process. Finally, via bioaugmentation where microorganisms developed in the laboratory are added to the system as the supplemental organisms, which should be more efficient than native to degrade the target pollutant (Agnello et al., 2016; Joutey et al., 2013). Bioaugmentation enables the upsurge of biodegradative capacities of polluted sites by introducing the strains with desired catalytic capabilities. The exploitation of microorganisms with proven degradation capability and survivability in the contaminated environment is crucial for an effective bioaugmentation.

Numerous studies have been conducted on the capability of microorganisms to transform toxic compounds into non-toxic forms. From the studies, it has been concluded that there are several microorganisms with the ability to transform harmful pollutants into intermediates, which can be included in the environmental exchange matter usually via adaptation mechanism. After years of investigation on biodegradation of aromatic compound, a number of microorganisms species, mostly mesophilic, 
have been identified capable of tolerating as well as degrading phenol and its derivatives (Yan et al., 2005; Wang et al., 2010; Krastanov et al., 2013; Arif et al., 2013; Bonfá et al., 2013; Liu et al., 2016; Jiang et al., 2016; Patel et al., 2017).

\section{Microbial degradation of phenol at cold climate}

Despite the fact that bioremediation has been widely accepted as a feasible approach to remove POPs like phenol from the environment due to its beneficial properties (Fuentes et al., 2010), most of the studies were carried out at mesophilic temperature but very few at low temperature. Recently, there has been switch of the direction of interest due to the mannerism of POPs in cold climate. At low temperature, the rate of biodegradation of POPs like phenol will be affected due to the change in their physical nature such as reduced bioavailability, increased viscosity as well as decreased volatilisation (Bajaj \& Singh, 2015). Besides, cold conditions largely affect the microbial activity by causing reduction in reaction rates since degradation process ought to obey the Arrhenius law (Subramaniam et al., 2019). As per the rule of Arrhenius law, the degradation of a contaminant is highly reliant on temperature in where an increase or decrease in temperature can influence the rate of reaction. In concordance, surviving at low temperature for microbes require a vast array of adaptive features including membranes and energy-producing systems, possession of novel cryotolerance presenting compounds and factors responsible for nutrient uptake, and adaptive proteins (Cavicchioli et al., 2002; Bajaj \& Singh, 2015). These features could only be attained through long term natural selection and is genetically encrypted within the protein sequence (Bajaj \& Singh, 2015). Such microorganisms can be found at cold-climate sites as they have already adapted to the condition and has the potential to thrive and grow at low temperature. Series of studies for phenol degradation have been done using psychrophilic or psychrotolerant microorganism as shown in Table 2. Cold-adapted bacteria can be classified into psychrophilic and psychrotrophic according to Morita (1975) where psychrophile (cold-loving) has an optimum growth temperature of $15^{\circ} \mathrm{C}$ or less and suppress growth above $20^{\circ} \mathrm{C}$, while psychrotroph (cold-tolerant) has a maximum growth at temperature above $15^{\circ} \mathrm{C}$ and $20^{\circ} \mathrm{C}$, but do not grow at temperature above $30^{\circ} \mathrm{C}$ (Margesin \& Schinner, 2001).

Nevertheless, the Antarctic Treaty forbids the importation of extraneous organisms into the Antarctic region, hence, only native microbes are allowed for the bioremediation purposes (Aislabie et al., 2000). Table 3 shows some of native microorganisms that have already been identified as a potential phenol degrader.

Table 2. Cold-adapted microorganisms involved in the biodegradation of phenol.

\begin{tabular}{|c|c|c|}
\hline Microbial species & Type of sample & Reference \\
\hline $\begin{array}{c}\text { Shinella sp. ATR202 Shinella sp. ATR2056 } \\
\text { Pseudomonas sp. ATR208 Stenotrophomonas } \\
\text { sp. ATR2042 } \\
\text { (Bacteria) }\end{array}$ & $\begin{array}{l}\text { Altitudes of 1,000 and 2,000 m of Binaloud } \\
\text { Mountains in the northeast of Iran }\end{array}$ & $\begin{array}{l}\text { Sepehr et al., } \\
2019\end{array}$ \\
\hline $\begin{array}{c}\text { Candida subhashii, Candida oregonensis } \\
\text { Schizoblastosporion starkeyi-henricii } \\
\text { (Yeast) }\end{array}$ & Rucianka raised bog in northern-east Poland & $\begin{array}{l}\text { Filipowicz et } \\
\text { al., } 2017\end{array}$ \\
\hline $\begin{array}{c}\text { Pseudomonas putida LY1 } \\
\text { (Bacteria) }\end{array}$ & Songhua River sediment & $\begin{array}{l}\text { Wang et al., } \\
2015\end{array}$ \\
\hline $\begin{array}{l}\text { Rhodotorula creatinivora } \\
\text { (Yeast) }\end{array}$ & $\begin{array}{l}\text { Alpine oil-shale mine and a railway area in } \\
\text { Austria }\end{array}$ & $\begin{array}{l}\text { Krallish et al., } \\
2006\end{array}$ \\
\hline $\begin{array}{c}\text { Arthrobacter psychrophenolicus } \\
\text { (Bacteria) }\end{array}$ & Alpine ice cave & $\begin{array}{l}\text { Margesin et al., } \\
2004\end{array}$ \\
\hline
\end{tabular}


Table 3. Antarctic microorganisms involved in the biodegradation of phenol.

\begin{tabular}{|c|c|c|}
\hline Microbial species & Type of sample & Reference \\
\hline $\begin{array}{c}\text { Arthrobacter sp. (AQ5-15) } \\
\text { (Bacteria) }\end{array}$ & Antarctic base soil & $\begin{array}{l}\text { Subramaniam et } \\
\text { al., } 2019\end{array}$ \\
\hline $\begin{array}{l}\text { Rhodococcus baikonurensis (AQ5-001) } \\
\text { (Bacteria) }\end{array}$ & Contaminated Antarctic soil & $\begin{array}{l}\text { Zakaria et al., } \\
\quad 2018\end{array}$ \\
\hline $\begin{array}{c}\text { Arthrobacter Bambusae (AQ5-003) } \\
\text { (Bacteria) }\end{array}$ & Contaminated Antarctic soil & $\begin{array}{l}\text { Ahmad et al., } \\
\quad 2018\end{array}$ \\
\hline $\begin{array}{c}\text { Arthrobacter sp. (AQ5-05; AQ5-06) } \\
\text { Rhodococcus sp. (AQ5-07) } \\
\text { (Bacteria) }\end{array}$ & Antarctic soil contaminated with phenol & Lee et al., 2017 \\
\hline $\begin{array}{l}\text { Basidiomycetous } \\
\text { Ascomycetous } \\
\text { (41 Yeast isolates) }\end{array}$ & Contaminated and pristine Antarctic soil & $\begin{array}{l}\text { Fernández et } \\
\text { al., } 2017\end{array}$ \\
\hline $\begin{array}{c}\text { Aspergillus fumigatus (AL8; AL9; AMA1102) } \\
\text { (Fungus) }\end{array}$ & Antarctic soil & $\begin{array}{l}\text { Gerginova et } \\
\text { al., } 2013\end{array}$ \\
\hline $\begin{array}{l}\text { Penicillium sp. } \\
\text { Aspergillus sp. } \\
\text { (Fungi) }\end{array}$ & Soil sample from Livingston Island, Antarctica & $\begin{array}{l}\text { Alexieva et al., } \\
\quad 2012\end{array}$ \\
\hline
\end{tabular}

\section{Mechanism of phenol biodegradation}

Bacteria can convert phenol and its derivatives into non-lethal intermediates either anaerobically (absence of oxygen), which is through a single pathway or aerobically (presence of oxygen), which is through meta- or ortho- pathway. Even so, most of the Antarctic microorganisms have reported to use aerobic pathway for phenol metabolism and anaerobic degradation of phenol that occurs in the absence of oxygen has been reported to be less advanced than the aerobic degradation. Degradation of phenol by bacteria is possible via the action of various enzymes such as oxygenases, hydroxylases, peroxidases, tyrosinases and oxidases (Nair et al., 2008). The first step of both pathways in aerobic degradation involves the monohydroxylation of the aromatic ring's ortho position. In aerobic phenol degradation, phenol hydroxylase (EC 1.14.13.7) plays the main role as it converts phenol into catechol, which is stated to be the initial and ratelimiting step in phenol degradation pathways. In line with that, a number of phenol hydroxylase have been purified from numerous bacterial species such as Diaphorobacter sp. J5-51, Acinetobacter sp. SJ-15, Acinetobacter sp. SJ-16, Acidovorax sp. J5-66 and Corynebacterium sp. JOR20 (Sun et al., 2014) and Acinetobacter sp. strain AQ5NOL 1 (Ahmad et al., 2017). The catechol produced is then completely degraded by catechol dioxygenase via meta- or ortho-cleavage pathways. In ortho-cleavage pathway, catechol is metabolised by catechol 1,2-dioxygenase to produce cis, cismuconate whereas in meta-cleavage pathway, catechol is metabolised by catechol 2,3dioxygenase to produce 2-hydroxymuconic semialdehyde (Ahmad et al., 2017).

The cis, cis-muconate produced in the orthocleavage pathway is then lactonised into muconolactone, which is then rearranged into 3oxoadipate-enol-lactone by isomerase. This 3oxoadipate-enol-lactone is further degraded by enzymes into 3-oxoadipyl CoA, which can act as substrate that can be converted into substrate to enter tricarboxylic acid cycle. Meanwhile, the 2hydroxymuconic semialdehyde produced in the meta-cleavage pathway is dehydrolysed into 4oxalocrotonic lactone where the carbon compound will then be detached from it by decarboxylase producing 2-oxopent-4-enoate. This compound is further degraded by enzymes into acetaldehyde and pyruvate, which then enter the tricarboxylic acid cycle (Basha et al., 2010). In a nutshell, both pathways at the end produce molecules can act as substrates in the tricarboxylic acid cycle as a final product. The summary of the aerobic metabolic pathway of phenol is shown in Figure 2. 


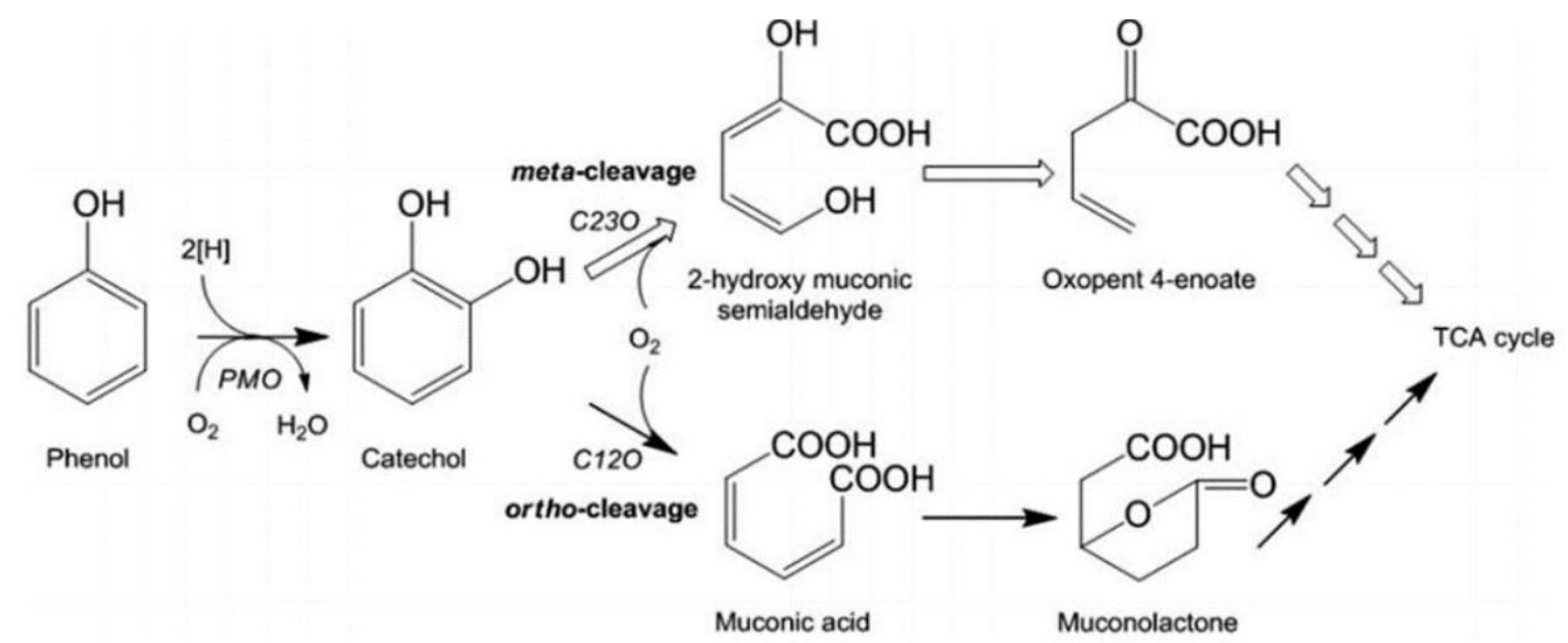

Figure 2. Aerobic pathway for phenol metabolism (Mazuki et al., 2019).

\section{Mixed culture method as a prospect for future bioremediation application in Antarctica}

First, researchers back then believed that pure culture can be a suitable model for scientific studies compared to mixed culture and it was difficult to carry out experimental analysis using mixed cultures (Bull, 1984). Although microorganisms generally occur in consortium in the environment, researchers have mainly focused on pure culture technique as a main driving force in the emerging science field. According to a study, the neglect of continuous studies on mixed microbial culture might be contributed by several reasons.

In recent years, studies on mixed microbial cultures over single species have attracted the attention of many researchers due to their advantages. The biodegradation capability of mixed culture has been said to be far more effective, qualitatively as well as quantitatively, than pure culture that can be mostly interpreted in biochemical terms such as commensal and synergistic interactions, relief of substrate inhibition and also co-metabolism. Accordingly, mixed culture possesses greater metabolic capacity compared to pure culture, which enables it to show higher degradation rate (Bull, 1984). The complete degradation of the pollutants due to the synergistic interactions among the members of the mixed bacterial associations (Cerqueira et al., 2011) and its ability to effectively evolve according to its environmental condition (Arnosti et al., 2016) makes this mixed culture technique a better candidate to be applied in biodegradation. To support the statement, it has been stated that the intermediates of the catabolic metabolism of one strain can be further degraded with the aid of another strain due to the synergistic interaction among the members of the associations, which results in a more effective metabolism and a complete degradation (Bhattacharya et al., 2015).

Therefore, plenty of studies have been carried out using mixed microbial culture technique in biodegradation of pollutants. A study on oily sludge degradation revealed that three bacteria isolates from petrochemical oily sludge identified as Stenotrophomonas acidaminiphila, Bacillus megaterium and Bacillus cibi, as well as two bacterial species isolated from soil contaminated by petrochemical waste identified as Pseudomonas aeruginosa and Bacillus cereus work more effectively in consortium compared to single species (Cerqueira et al., 2011). Besides, a study on waste lubricating oil removal proved that mixed culture of Ochrobactrum sp. C1 and Bacillus sp. K1 isolated from lubricating oil contaminated soil has notably influenced the degradation capability of the pure isolates through bioaugmentation process (Bhattacharya et al., 2015). Moreover, profenofos, an organophosphate insecticide, has been effectively degraded by the consortium of bacteria comprising Achromobacter xylosoxidans, Pseudomonas aeruginosa, Bacillus sp. and Citrobacter koseri in comparison with pure cultures (Jabeen et al., 2015).

In the year 2010, Dey and Mukherjee studied the mechanism of phenol biodegradation by 
mixed microbial culture collected from coke oven industry effluent using a batch reactor. It has been reported from their study that the mixed culture has effectively degraded phenol up to $700 \mathrm{mg} / \mathrm{L}$ concentration under aerobic condition (Dey \& Mukherjee, 2010). In the year 2014, a study reported that mixed bacterial strains of Pseudomonas putida Tan-1 and Staphylococcus aureus Tan-2 showed higher degradation rate at a maximum concentration of $800 \mathrm{mg} / \mathrm{L}$ phenol compared to the individual cultures (Senthilvelan et al., 2014). Additionally, the mixed bacterial strains of Flavobacterium sp. and Acetobacter sp., which have the capability to degrade phenol in a short period of time as well as higher tolerance limit individually, posed even rapid and more effective degradation of phenol compared to each strain separately (Zeng et al., 2014).

Since there are plenty of studies proving the efficiency of mixed culture method over pure culture method for pollutant degradation, it can be a potential approach to be applied in Antarctica using native microorganisms. Nevertheless, this approach faced difficulties from numerous limitations like limited capability of microbial species in the field and the absence of benchmark values to test the effectiveness of this technique for its extensive application in the field (Bhattacharya et al., 2015). The improvement in the bioremediation strategies to overcome these limitations is still a challenge. In order to improve this method, further studies on mixed culture method should be done using Antarctic microorganisms to investigate the possibility of the method when it comes to application.

\section{CONCLUSION}

Since this modern civilisation will most probably continue to be accompanied by the production of the priority pollutants like phenol, it is crucial to be involved in the new development of effective strategies for biodegradation especially when it comes to recovering and remediating polluted Antarctic environment as it can be considered as one of the last pristine environments on Earth. The study of phenol remediation is still relevant and necessary till date, especially in Antarctica due to the continent's extremely cold and harsh climate. Biodegradation of phenol and its derivatives using microbial species has become the hot topic in bioremediation field for several decades and utilisation of Antarctic microbes as phenol degraders comply the rule of Antarctic Treaty which forbids the importation of foreign organisms into the continent. In future, method like microbial-aggregation can be used for phenol degradation in Antarctica as this approach reported to be more efficient and effective.

\section{ACKNOWLEDGEMENTS}

This work was supported by High Impact Grant Putra (GPM-2018/9660000), PUTRA-IPS (9631800) and YPASM Berth Support / Matching Grant PUTRA (UPM-YPASM 9300430). We also thank Universiti Putra Malaysia for providing a GRF scholarship to Kavilasni Subramaniam.

\section{REFERENCES}

Abbasian, F., Lockington, R., Mallavarapu, M., \& Naidu, R. 2015. A comprehensive review of aliphatic hydrocarbon biodegradation by bacteria. Applied Biochemistry and Biotechnology 176(3): 670-699.

Abussaud, B., Asmaly, H. A., Saleh, T. A., Gupta, V. K., \& Atieh, M. A. 2016. Sorption of phenol from waters on activated carbon impregnated with iron oxide, aluminum oxide and titanium oxide. Journal of Molecular Liquids 213: 351-359.

Agnello, A. C., Bagard, M., Van Hullebusch, E. D., Esposito, G., \& Huguenot, D. 2016. Comparative bioremediation of heavy metals and petroleum hydrocarbons cocontaminated soil by natural attenuation, phytoremediation, bioaugmentation and bioaugmentation-assisted phytoremediation. Science of the Total Environment 563-564: 693-703.

Ahmad, S. A., Shamaan, N. A., Arif, N. M., Koon, G. B., Shukor, M. Y. A., \& Syed, M. A. 2012. Enhanced phenol degradation by immobilized Acinetobacter sp. strain AQ5NOL 1. World Journal of Microbiology and Biotechnology 28(1): 347-352.

Ahmad, S. A., Shamaan, N. A., Syed, M. A., Khalid, A., Ab Rahman, N. A., Abdul Khalil, K., Dahalan, F. A., \& Shukor, M. Y. 2017. Meta-cleavage pathway of phenol degradation by Acinetobacter sp. strain AQ5NOL 1. Rendiconti Lincei 28(1): $1-9$.

Ahmad, S. A., Asokan, G., Yasid, N. A., Nawawi, N. M., Subramaniam, K., Zakaria, N. N., \& Shukor, M. Y. 2018. Effect of heavy metals on biodegradation of phenol by Antarctic bacterium: Artbrobacter bambusae strain AQ5-003. Malaysian Journal of Biochemistry and Molecular Biology 21(2): 4751.

Aislabie, J., Foght, J., \& Saul, D. 2000. Aromatic hydrocarbondegrading bacteria from soil near Scott Base, Antarctica. Polar Biology 23(3): 183-188. 
Al_Defiery, M. E. J., \& Reddy, G. 2014. Influence of metal ions concentration on phenol degradation by Rhodococcus pyridinivorans GM3. Mesopotamia Environmental Journal 1(1): 30-38.

Alexieva, Z., Yemendzhiev, H., Tossi, S., Krumova, E., Angelova, M., Terziyska, A., Peneva, N., \& Gerginova, M. 2012. Growth of fungal strains isolated from Livingston Island on phenolic compounds - biodegradation potential. In: Microbes in Applied Research Ed. Méndez-Vilas, A. pp. 131-134 Malaga: World Scientific.

Almroth, B. C., Asker, N., Wassmur, B., Rosengren, M., Jutfelt, F., Gräns, A., Sundell, K., Axelsson, M., \& Sturve, J. 2015. Warmer water temperature results in oxidative damage in an Antarctic fish, the bald notothen. Journal of Experimental Marine Biology and Ecology 468: 130-137.

An, T., Huang, Y., Li, G., He, Z., Chen, J., \& Zhang, C. 2014. Pollution profiles and health risk assessment of VOCs emitted during e-waste dismantling processes associated with different dismantling methods. Environment International 73: 186-194.

Arif, N. M., Ahmad, S. A., Syed, M. A., \& Shukor, M. Y. 2013. Isolation and characterization of a phenol-degrading Rhodococcus sp. strain AQ5NOL 2 KCTC 11961BP. Journal of Basic Microbiology 53(1): 9-19.

Arnosti, C., Ziervogel, K., Yang, T., \& Teske, A. 2016. Oil-derived marine aggregates - hot spots of polysaccharide degradation by specialized bacterial communities. Deep Sea Research Part II: Topical Studies in Oceanography 129(Supplement C): 179-186.

Babich, H. \& Davis, D. L. 1981. Phenol: a review of environmental and health risks. Regulatory Toxicology and Pharmacology 1(1): 90-109.

Bajaj, S. \& Singh, D. K. 2015. Biodegradation of persistent organic pollutants in soil, water and pristine sites by cold-adapted microorganisms: Mini review. International Biodeterioration and Biodegradation 100: 98-105.

Barrett, J. R. 2010. Opening the window to cancer: potential mechanism behind increased susceptibility in rats exposed prenatally to BPA. Environmental Health Perspectives 118(11): A490.

Basha, K. M., Rajendran, A., \& Thangavelu, V. 2010. Recent advances in the biodegradation of phenol: a review. Asian Journal of Experimental Biological Sciences 1(2): 219-234.

Bhattacharya, M., Guchhait, S., Biswas, D., \& Datta, S. 2015. Waste lubricating oil removal in a batch reactor by mixed bacterial consortium: a kinetic study. Bioprocess and Biosystems Engineering 38(11): 2095-2106.

Bonfá, M. R. L., Grossman, M. J., Piubeli, F., Mellado, E., \& Durrant, L. R. 2013. Phenol degradation by halophilic bacteria isolated from hypersaline environments. Biodegradation 24(5): 699-709.

Bull, A. T. 1984. Mixed microbial culture technology. Biochemical Society Transactions 12(6): 1137-1138.

Cavicchioli, R., Siddiqui, K. S., Andrews, D., \& Sowers, K. R. 2002. Low-temperature extremophiles and their applications. Current Opinion in Biotechnology 13(3): 253-261.

Cerqueira, V. S., Hollenbach, E. B., Maboni, F., Vainstein, M. H., Camargo, F. A. O., Peralba, M. do C. R., \& Bento, F. M. 2011. Biodegradation potential of oily sludge by pure and mixed bacterial cultures. Bioresource Technology 102(23): 11003-11010.

Cox, C. 1996. Nonyl phenol and related chemicals. Journal of Pesticide Reform 16(1): 15-20.

de Renzy-Martin, K. T., Frederiksen, H., Christensen, J. S., Kyhl, H. B., Andersson, A.-M., Husby, S., Barington, T., Main, K. M., \& Jensen, T. K. 2014. Current exposure of 200 pregnant Danish women to phthalates, parabens and phenols. Reproduction 147(4): 443-453.
Dey, S., \& Mukherjee, S. 2010. Performance and kinetic evaluation of phenol biodegradation by mixed microbial culture in a batch reactor. International Journal of Water Resources and Environmental Engineering 2(3): 40-49.

Duan, W., Meng, F., Cui, H., Lin, Y., Wang, G., \& Wu, J. 2018. Ecotoxicity of phenol and cresols to aquatic organisms: a review. Ecotoxicology and Environmental Safety 15(157): 441456.

Elahwany, A. \& Mabrouk, M. 2013. Isolation and characterization of a phenol-degrading strain of Alcaligenes sp. AM4. Acta Biologica Hungarica 64(1): 106-117.

Ereqat, S. I., Abdelkader, A. A., Nasereddin, A. F., Al-Jawabreh, A. O., Zaid, T. M., Letnik, I., \& Abdeen, Z. A. 2017. Isolation and characterization of phenol degrading bacterium strain Bacillus thuringiensis J20 from olive waste in Palestine. Journal of Environmental Science and Health, Part A, Toxic/Hazardous Substances and Environmental Engineering 53(1): 39-45.

Fialová, A., Boschke, E., \& Bley, T. 2004. Rapid monitoring of the biodegradation of phenol-like compounds by the yeast Candida maltosa using BOD measurements. International Biodeterioration and Biodegradation 54(1): 69-76.

Filipowicz, N., Momotko, M., Boczkaj, G., Pawlikowski, T., Wanarska, M., \& Cieśliński, H. 2017. Isolation and characterization of phenol-degrading psychrotolerant yeasts. Water, Air, and Soil Pollution 228(6): 210.

Filler, D. M., Reynolds, C. M., Snape, I., Daugulis, A. J., Barnes, D. L., \& Williams, P. J. 2006. Advances in engineered remediation for use in the Arctic and Antarctica. Polar Record 42(2): 111-120.

Flynn, E. E., Bjelde, B. E., Miller, N. A., \& Todgham, A. E. 2015. Ocean acidification exerts negative effects during warming conditions in a developing Antarctic fish. Conservation Physiology 3(1): 1-16.

Fuentes, M. S., Benimeli, C. S., Cuozzo, S. A., \& Amoroso, M. J. 2010. Isolation of pesticide-degrading actinomycetes from a contaminated site: bacterial growth, removal and dechlorination of organochlorine pesticides. International Biodeterioration \& Biodegradation 64(6): 434-441.

Griffiths, H. J., \& Waller, C. L. 2016. The first comprehensive description of the biodiversity and biogeography of Antarctic and Sub-Antarctic intertidal communities. Journal of Biogeography 43(6): 1143-1155.

Habib, S., Ahmad, S. A., Johari, W. L. W., Shukor, M. Y. A., \& Yasid, N. A. 2018. Bioremediation of petroleum hydrocarbon in Antarctica by microbial species: an overview. Pertanika Journal of Science and Technology 26(1): 120.

Henry, N. D., \& Fair, P. A. 2013. Comparison of in vitro cytotoxicity, estrogenicity and anti-estrogenicity of triclosan, perfluorooctane sulfonate and perfluorooctanoic acid. Journal of Applied Toxicology 33(4): 265-272.

Jabeen, H., Iqbal, S., Anwar, S., \& Parales, R. E. 2015. Optimization of profenofos degradation by a novel bacterial consortium PBAC using response surface methodology. International Biodeterioration and Biodegradation 100: 89-97.

Jiang, Y., Shang, Y., Yang, K., \& Wang, H. 2016. Phenol degradation by halophilic fungal isolate JS4 and evaluation of its tolerance of heavy metals. Applied Microbiology and Biotechnology 100(4): 1883-1890.

Joutey, N. T., Bahafid, W., Sayel, H., \& El Ghachtouli, N. 2013. Biodegradation: involved microorganisms and genetically engineered microorganisms. In Biodegradation-life of Science Ed. Rolando, C. doi:10.5772/56194 Valparaiso, InTech.

Kanematsu, H., \& Barry, D. M. 2015. Environmental problems: soil and underground water treatment and bioremediation. 
In Biofilm and Materials Science Eds. Kanematsu, H \& Barry, D. M. pp. 117-123 Springer.

Krallish, I., Gonta, S., Savenkova, L., Bergauer, P., \& Margesin, R. 2006. Phenol degradation by immobilized cold-adapted yeast strains of Cryptococcus terreus and Rhodotorula creatinivora. Extremophiles 10(5): 441-449.

Krastanov, A., Alexieva, Z. \& Yemendzhiev, H. 2013. Microbial degradation of phenol and phenolic derivatives. Engineering in Life Sciences 13(1): 76-87.

Krause, M., Klit, A., Blomberg Jensen, M., Søeborg, T., Frederiksen, H., Schlumpf, M., Lichtensteiger, W., Skakkebaek, N.E., \& Drzewiecki, K. T. 2012. Sunscreens: are they beneficial for health? An overview of endocrine disrupting properties of UV-filters. International Journal of Andrology 35(3): 424-436.

Kulshreshtha, A., Agrawal, R., Barar, M., \& Saxena, S. 2014. A review on bioremediation of heavy metals in contaminated water. International Journal of Environmental Science, Toxicology and Food Technology 8: 44-50.

Lee, G. L. Y., Ahmad, S. A., Yasid, N. A., Zulkharnain, A., Convey, P., Johari, W. L. W., Alias, S. A., Gonzalez-Rocha, G., \& Shukor, M. Y. 2017. Biodegradation of phenol by coldadapted bacteria from Antarctic soils. Polar Biology 41(3): 110.

Lee, S. Y. \& Abdullah, J. O. 2017. Phenol toxicity and remediation. Pertanika Journal of Scholarly Research Reviews 3(3): 107-120.

Liu, Z., Xie, W., Li, D., Peng, Y., Li, Z., \& Liu, S. 2016. Biodegradation of phenol by bacteria strain Acinetobacter calcoaceticus PA isolated from phenolic wastewater. International Journal of Environmental Research and Public Health 13(3): 300.

Margesin, R. \& Schinner, F. 2001. Biodegradation and bioremediation of hydrocarbons in extreme environments. Applied Microbiology and Biotechnology 56(5): 650-663.

Margesin, R., Schumann, P., Spröer, C., \& Gounot, A. M. 2004. Artbrobacterpsychrophenolicus sp. nov., isolated from an Alpine ice cave. International Journal of Systematic and Evolutionary Microbiology 54(6): 2067-2072.

Mazuki, T. A. T., Shukor, M. Y., \& Ahmad, S. A. 2019. Bioremediation of phenol in Antarctic: a mini review. Malaysian Journal of Biochemistry and Molecular Biology 22(1): 16.

McWatters, R. S., Wilkins, D., Spedding, T., Hince, G., Raymond, B., Lagerewskij, G., Terry, D., Wise, L., \& Snape, I. 2016. On site remediation of a fuel spill and soil reuse in Antarctica. Science of the Total Environment 571: 963-973.

Meckenstock, R. U., Boll, M., Mouttaki, H., Koelschbach, J. S., Tarouco, P. C., Weyrauch, P., Dong, X., \& Himmelberg, A. M. 2016. Anaerobic degradation of benzene and polycyclic aromatic hydrocarbons. Journal of Molecular Microbiology and Biotechnology 26(1-3): 92-118.

Michalowicz, J., \& Duda, W. (2007). Phenols-sources and toxicity. Polish Journal of Environmental Studies 16(3): 347-362.

Millow, C. J. 2015. Contaminants and reproductive output in a sentinel seabird, the black skimmer (Rynchops niger). Doctoral dissertation, San Diego State University.

Mohammadi, S., Kargari, A., Sanaeepur, H., Abbassian, K., Najafi, A., \& Mofarrah, E. 2015. Phenol removal from industrial wastewaters: a short review. Desalination and Water Treatment 53(8): 2215-2234.

Morita, R. Y. 1975. Psychrophilic bacteria. Bacteriological Reviews 39(2): 144-167.

Mukherjee, D., Guha, D., Kumar, V., Chakraborty, S. 1991 Impairment of steroidgenesis and reproduction in sexually mature Cyprinus carpio by phenol and sulfide under laboratory conditions. Aquatic Toxicology 21: 29-40.

Naghan, D. J., Azari, A., Mirzaei, N., Velayati, A., Tapouk, F. A., Adabi, S., Pirsaheb, M., \& Sharafi, K. 2015. Parameters effecting on photocatalytic degradation of the phenol from aqueous solutions in the presence of $\mathrm{ZnO}$ nanocatalyst under irradiation of UV-C light. Bulgarian Chemical Communications 47: 14-18.

Nair, C. I., Jayachandran, K., \& Shashidhar, S. 2008. Biodegradation of phenol. African Journal of Biotechnology 7(25): 4951-4958.

Nawawi, N. M., Ahmad, S. A., Shukor, M. Y., Syed, M. A., Khalil, K. A., Ab Rahman, N. A., Dahalan, F. A., \& Ibrahim, A. L. 2016. Statistical optimisation for improvement of phenol degradation by Rhodococcus sp. NAM 81. Journal of Environmental Biology 37(3): 443-451.

Ni, Y., Xia, Z., \& Kokot, S. 2011. A kinetic spectrophotometric method for simultaneous determination of phenol and its three derivatives with the aid of artificial neural network. Journal of Hazardous Materials 192(2): 722-729.

Park, J. S., Brown, M. T., \& Han, T. 2012. Phenol toxicity to the aquatic macrophyte Lemna paucicostata. Aquatic Toxicology 106: $182-188$

Patel, A., Sartaj, K., Arora, N., Pruthi, V., \& Pruthi, P. A. 2017. Biodegradation of phenol via meta cleavage pathway triggers de novo TAG biosynthesis pathway in oleaginous yeast. Journal of Hazardous Materials 340: 47-56.

Patil, S. S. \& Jena, H. M. 2016. Isolation and characterization of phenol degrading bacteria from soil contaminated with paper mill wastewater. Indian Journal of Biotechnology 15(3): 407-411.

Plahuta, M., Tišler, T., Toman, M. J., \& Pintar, A. 2017. Toxic and endocrine disrupting effects of wastewater treatment plant influents and effluents on a freshwater isopod Asellus aquaticus (Isopoda, Crustacea). Chemosphere 174: 342-353.

Pradeep, N. V., Anupama, S., Navya, K., Shalini, H. N., Idris, M., \& Hampannavar, U. S. 2015. Biological removal of phenol from wastewaters: a mini review. Applied Water Science 5(2): 105-112.

Roslee, A. F. A., Zakaria, N. N., Convey, P., Zulkharnain, A., Lee, G. L. Y., Gomez-Fuentes, C., \& Ahmad, S.A. 2019. Statistical optimisation of growth conditions and diesel degradation by the Antarctic bacterium, Rhodococcus sp. strain AQ5-07. Extremophiles 23.

Saha, N. C., Bhunia, F., \& Kaviraj, A. 1999. Toxicity of phenol to fish and aquatic ecosystems. Bulletin of Environmental Contamination and Toxicology 63(2): 195-202.

Santos, V. L. \& Linardi, V. R. 2004. Biodegradation of phenol by a filamentous fungus isolated from industrial effluentsidentification and degradation potential. Process Biochemistry 39(8): 1001-1006.

Senthilvelan, T., Kanagaraj, J., Panda, R. C., \& Mandal, A. B. 2014. Biodegradation of phenol by mixed microbial culture: an eco-friendly approach for the pollution reduction. Clean Technologies and Environmental Policy 16(1): 113-126.

Sepehr, S., Shahnavaz, B., Asoodeh, A., \& Karrabi, M. 2019. Biodegradation of phenol by cold-tolerant bacteria isolated from alpine soils of Binaloud Mountains in Iran. Journal of Environmental Science and Health, Part A 54(4): 367-379.

Singh, S., Mishra, R., Sharma, R. S., \& Mishra, V. 2017. Phenol remediation by peroxidase from an invasive mesquite: Turning an environmental wound into wisdom. Journal of Hazardous Materials 334 (supplement C): 201-211.

Sivakumar, D., Kandaswamy, A. N., Gomathi, V., Rajeshwaran, R., \& Murugan, N. 2014. Bioremediation studies on reduction of heavy metals toxicity. Pollution Research 33: 553 558.

Song, Z., \& Huang, G. 2007. Toxic effects of pentachlorophenol on Lemna polyrbiza. Ecotoxicology and Environmental Safety 66(3): 343-347.

Sontag, P. T., Steinberg, D. K., \& Reinfelder, J. R. 2019. Patterns of total mercury and methylmercury bioaccumulation in 
Antarctic krill (Euphausia superba) along the West Antarctic Peninsula. Science of The Total Environment 688: 174-183.

Stoilova, I., Krastanov, A., Stanchev, V., Daniel, D., Gerginova, M., \& Alexieva, Z. 2006. Biodegradation of high amounts of phenol, catechol, 2,4-dichlorophenol and 2,6dimethoxyphenol by Aspergillus awamori cells. Ensyme and Microbial Technology 39(5): 1036-1041.

Subramaniam, K., Mazuki, T. A. T., Shukor, M. Y., \& Ahmad, S. A. 2019. Isolation and optimisation of phenol degradation by Antarctic isolate using one factor at time. Malaysian Journal of Biochemistry and Molecular Biology 22(1): 79-86.

Sun, J.-Q., Xu, L., Tang, Y.-Q., Chen, F.-M., Zhao, J.-J., \& Wu, X.L. 2014. Bacterial pyridine hydroxylation is ubiquitous in environment. Applied Microbiology and Biotechnology 98(1): 455464.

Toullec, J. Y., Corre, E., Mandon, P., Gonzalez-Aravena, M., Ollivaux, C., \& Lee, C. Y. 2017. Characterization of the neuropeptidome of a Southern Ocean decapod, the Antarctic shrimp Chorismus antarcticus: Focusing on a new decapod ITP-like peptide belonging to the $\mathrm{CHH}$ peptide family. General and Comparative Endocrinology 252: 60-78.

Varjani, S. J. 2017. Microbial degradation of petroleum hydrocarbons. Bioresource Technology 223: 277-286.

Vasudevan, S. 2014. An efficient removal of phenol from water by peroxi-electrocoagulation processes. Journal of $W$ ater Process Engineering 2: 53-57.

Villegas, L. G. C., Mashhadi, N., Chen, M., Mukherjee, D., Taylor, K. E., \& Biswas, N. 2016. A short review of techniques for phenol removal from wastewater. Current Pollution Reports 2(3): 157-167.

Wang, L., Li, Y., Yu, P., Xie, Z., Luo, Y., \& Lin, Y. 2010. Biodegradation of phenol at high concentration by a novel fungal strain Paecilomyces variotii JH6. Journal of Hazardous Materials 183(1): 366-371.

Yahaya, A., Okoh, O. O., Agunbiade, F. O., \& Okoh, A. I. 2019. Occurrence of phenolic derivatives in Buffalo River of Eastern Cape South Africa: Exposure risk evaluation. Ecotoxicology and Environmental Safety 171: 887-893.

Yan, J., Jianping, W., Hongmei, L., Suliang, Y., \& Zongding, H. 2005. The biodegradation of phenol at high initial concentration by the yeast Candida tropicalis. Biochemical Engineering Journal 24(3): 243-247.

Zakaria, N. N., Ahmad, S. A., Yin, G. L. L., Yasid, N. A., Manogaran, M., Subramaniam, K., Mazuki, T. A. T., Nawawi, N. M., \& Shukor, M. Y. 2018. Biodegradation of phenol by Antarctic bacterium Rhodococcus baikonurensis strain AQ5-001 in the prersence of heavy metals. Malaysia Journal of Biochemistry and Molecular Biology 21(3): 29-36.

Zakaria, N.N., Man, Z., Zulkharnain, A., \& Ahmad, S.A. 2019. Psychrotolerant biosurfactant-producing bacteria for hydrocarbon degradation: a mini review. Malaysian Journal of Biochemistry and Molecular Biology 22(2), 52-59.

Zeng, H.-Y., Cao, X.-L., Xiong, L.-B., Cai, X.-L., Huang, L.-Q., Zhang, C.-Y., \& Li, Y.-Q. 2014. Microbiological degradation of phenol using two co-aggregating bacterial strains. Environmental Earth Sciences 71(3): 1339-1348.

Zhang, M., \& Yoshikawa, M. 2016. An overview of remediation technologies for sites contaminated with volatile organic compounds. In Geo-Chicago 2016: Sustainable Waste Management and Remediation Eds. Yesiller, N., Zekkos, D., Farid, A., De, A., \& Reddy, K. R. pp. 295-301 Chicago, American Society of Civil Engineers. 